\title{
Lives, Laboratories, and the Translations of War: British Medical Scientists, 1914 and Beyond.
}

The history of medicine and the history of the Great War meet most often on a limited number of fields: shell-shock, venereal diseases, medical specialization, and surgery, on the repair of wounded soldiers and the experiences of the doctors who worked with them. ${ }^{1}$ There is another side to this history, however, in the concerted effort that was made during the war to prevent and to deflect the ravages of infectious disease. ${ }^{2}$ It is well known that World War I was the first war in which casualties from wounds exceeded those from disease, at least on the Western Front, but the work and the research that went into disease prevention has gone largely unexplored by historians. ${ }^{3}$ Moreover it can be suggested that the war-related research was of considerable, constructive, and largely unsung importance to the medical understanding of several infectious conditions, and to the onward development of microbiology and tropical medicine. ${ }^{4}$ Bacteriology may have come of age in Britain in the mid-1890s, when it was incorporated into public health practice,

\footnotetext{
1 Mark Harrison, The Medical War. British Military Medicine in the First World War (Oxford: Oxford University Press, 2001), 13. See for example, Peter Leese, Shell Shock: Traumatic Neuroses and British Soldiers of the First World War (Basingstoke: Palgrave McMillan, 2002); Mark Harrison, 'The British Army and the problem of venereal disease and Egypt during the First World War', Medical History, 1995, 29, 133-58; Steve Sturdy, 'From the trenches to the hospitals at home: Physiologists, clinicians and oxygen therapy', in Medical Innovations in Historical Perspective, ed John Pickstone (London, 1992), 104-23; Joel Howell, "Soldier's heart": The redefinition of heart disease and specialty formation in the early twentieth century', in Roger Cooter et al eds, War, Medicine and Modernity (Stroud, Glos: Sutton Publishing Ltd, 1998), 85-105; Leo van Bergen, Before My Helpless Sight: Suffering, Dying and Military Medicine on the Western Front, 1914-1918 (Farnham: Ashgate, 2009); lan R. Whitehead, Doctors in the Great War (Barnsley: Leo Cooper, 1999).

2 Harrison, Medical War.

${ }^{3}$ See Harriette Chick, Margaret Hume, and Marjorie MacFarlane, War on Disease: A History of the Lister Institute (London: Andre Deutsch, 1971), 124-30; Appendix, 231-40.

${ }^{4}$ But see Leo B. Slater, War and Disease: Biomedical Research on Malaria in the Twentieth Century (New Brunswick, NJ: Rutgers University Press, 2009).
} 
but as a research endeavour it remained fragmented. ${ }^{5}$ In that decade, however, the practice of bacteriological research and bacteriologically-driven practice was

introduced into the Army by Almroth Wright at Netley, and in the years after the Boer War, bacteriology was incorporated into military medical consciousness. ${ }^{6}$ For the discipline of medical microbiology, in its infancy in 1914, the war years were critical in stimulating research into bacterial variation and into a number of infections previously of minor moment to the British public health community: meningitis, dysentery, and non-typhoid enteric fever. Nutrition science too benefitted from the problems of war and the acquisition of scientific recruits. In Britain these war-related researches were undertaken both abroad and at home, in the newly-established laboratory at the Royal Army Medical College at Millbank, in the Laboratory of the University War Hospital at Southampton, in a variety of other military hospitals, and in various civilian facilities, notably the Pathology Department of St Bartholomew's Hospital and the Chelsea laboratories of the Lister Institute for Preventive Medicine. On the continent of Europe and beyond, such researches were also undertaken in the mobile laboratories of the British and Austrian Armies. ${ }^{7}$ Nor was it simply medical knowledge that benefitted from this war effort: the lives and career patterns of some - perhaps many -- of those involved in this work were radically re-directed towards new fields of medical endeavour. The medicine of World War I was not only

\footnotetext{
${ }^{5}$ Michael Worboys, Spreading Germs. Disease Theories and Medical Practice in Britain, 1865-1900 (Cambridge: Cambridge University Press, 2000), chapter 7.

${ }^{6}$ Michael Worboys, 'Almroth Wright at Netley: Modern medicine in Britain, 1892-1902' in Roger Cooter, Mark Harrison and Steve Sturdy eds, Medicine and Modern Warfare (Amsterdam: Rodopi, 1999), 77-98.

${ }^{7}$ Harrison, Medical War, 136, notes that the mobile field laboratories were supplemented by a network of facilities in hospitals and civilian research institutions. See also Cay-Rüdiger Prull, 'Pathology at war 1914-1918: Germany and Britain in comparison', in Cooter, Harrison, and Sturdy, eds, Medicine and Modern Warfare, 136-37.
} 
about the salvaging of damaged minds and bodies: it expanded the horizons of preventive medicine and microbiology.

It has been a common thread in past history that war is good for medicine. This is an argument that revisionist historians have disputed, pointing out that it took time before battle-field innovations like blood transfusion and facial reconstruction became practical or applicable in civilian medicine. ${ }^{8}$ But the impact of the Great War on civilian medicine was more subtle than the mere translation of battlefield techniques. The great clinician Sir Clifford Allbutt noted that a 'scientific transformation' had been brought about by World War I: before the war, medicine was an 'observational and empirical craft', after, it had become a scientific calling. ${ }^{9}$ This transformation can be seen in bacteriology, a medical science born in the laboratory, although laboratory discipline was not as rigorous as it was later to become. ${ }^{10}$ The development was recognised by contemporaries: Frederick Andrewes, Professor of Pathology at St Bartholomew's Hospital, saw the war as transformative of his subject: 'The war to me, and I think to a great many others,' he wrote, 'forms a sort of landmark in bacteriology, as it does in history. I think I learned more bacteriology during the years of the war than in all the twenty years that preceded it'. ${ }^{11}$ The wartime effort towards controlling infectious disease in Britain,

\footnotetext{
8 See the discussion in Roger Cooter, 'Medicine and the goodness of war', Canadian Journal of Medical History, 1990, 9, 147-59.

${ }^{9}$ Cited in Cooter, 'War and modern medicine', 1546. Medicine was not the only profession to undergo profound translation under the stress of war: a generation of university mathematicians emerged from World War II as professional statisticians: Andrew Dilnot, 'A History of Britain in Numbers', BBC Radio 4, 27 February 2015.

${ }_{10}$ See Hardy, Salmonella Infections,

${ }^{11}$ Andrewes, 'Beginnings of bacteriology', 117. 
perhaps uniquely, concentrated and consolidated bacteriological practice in the country as never before. ${ }^{12}$

Many of the medical scientists engaged in this work were trained in bacteriology or pathology, but others were co-opted from different branches of medicine or even science. Some were women. ${ }^{13}$ Some worked in army hospitals, as did the bacteriologist Ralph St John Brooks, later in charge of the National Collection of Type Cultures at the Lister Institute, at the County of London War Hospital, and some were with mobile laboratories on the battlefields. ${ }^{14}$ Others remained in their own laboratories, as did Frederick Andrewes at St Bartholomew's Hospital. ${ }^{15}$ While historical attention has, understandably, largely focused on medicine as related to the combatant troops, essential contributions were also made by serving medical staff on the Home Front, whose willingness to take up new areas of, sometimes uncongenial, research, testifies to scientific flexibility and a willingness to serve the country in whatever capacity one could be useful. The British medical community across all its departments rose to the occasion of war.

The scale of medical involvement in the conflict, both combatant and noncombatant, fully justifies Mark Harrison's judgment of this as 'The Medical War'. By 31 December 1915, 66,139 men had 'been obtained' for the Royal Army Medical Corps; not all of these can have been doctors, but in all nearly half Britain's doctors were enrolled for military service. ${ }^{16}$ That the demand for medical personnel was

\footnotetext{
12 The situation in France, for example, in the example of influenza research, was very different: see Frédérick Vagneron, 'Aux frontiers de la maladie. L'histoire de la grippe pandémique en France (1889-1919)', PhD thesis (Paris, 2015), 647-59.

13 See lan R. Whitehead, Doctors in the Great War (Barnsley: Leo Cooper, 1999), 32-125.

14 See Anon, 'Ralph Terence St John Brooks', British Medical Journal, 1963, ii, 1238.

15 M.H.G., 'Frederick William Andrewes, Obituary Notices of Fellows of the Royal Society, 1932-34, 1, 37-40, 37; F.W. Andrewes, 'Dysentery bacilli', Lancet, 1918, i, 560.

${ }^{16}$ www.ramc.ww1.com/index.php, accessed 1 November 2014. This 'obtained' number must include non-medically-trained personnel: the Medical Registers for 1914, 1916, and 1919, which include
} 
relentless is clear. Even if a fraction of these were not actively practising medicine, and were scientists located in hospitals and laboratories doing war-related research, this was still a substantial proportion of the medical men listed in the Medical Register. The pressure on the home front was severe. In September 1915, over 6,000 members of the public health service were engaged in military duties, and by November the journal Medical Officer, which had hitherto encouraged its readership to enlist, was requesting the Local Government Board to take the army in hand: 'We suggest that the military authorities should be given to understand that the public health service is an essential unit for the defence of this realm, and it must therefore not be drawn on too heavily for military purposes'. ${ }^{17}$ Specialists in laboratory medicine were valuable, however: they were not generally deployed on the battlefields, except in association with the fitted motor mobile laboratories which were a novel feature in this particular conflict. ${ }^{18}$ In the field and at home, these medical scientists were engaged in studying problems of disease relevant to the war.

The medical scientists on whose lives this paper is based were broadly speaking engaged in microbiological research from circa 1900 to World War II and beyond. Reviewing the lives of the principal protagonists in this project of the interwar period, it was noticeable how many of their careers had been either temporarily deflected or radically altered by the experience of the Great War. In

RAMC officers and Territorials, list totals of registered practitioners for England, Scotland, and Ireland as $41,940,43,225$, and 43,926 in these years, suggesting an average military service enrolment of some 21,500 doctors. See Table D in the respective registers. By 1918, the RAMC consisted of 13,000 officers and 154,000 other ranks: www.ams-museum.org.uk/museum/history/ramc-history/ ${ }^{17}$ Editorial, 'Depletion of the Public Health Service', Medical Officer, 1915, 14, 201. On Medical Officers of Health and the military see Whitehead, Doctors, 44-46. For civilian recognition of this situation see Anon, 'A plea for consideration', Lancet, 1915, i, 611-12.

18 Major A. C. H. Gray, 'Mobile laboratories', Guy's Hospital Reports, 1922, 20, 257-71, 262. Gray himself served in France in charge of the second mobile laboratory, the Princess Christian, from January 1915: The War, 'The Princess Christian Motor Laboratory', Lancet, 1915, i, 207. This article contains photographs of the interior and exterior of the laboratory. 
many cases also, their war work fed in to research pre-occupations of the interwar period. Prosopography is a recognised route by which to explore the workings of organisations and institutions, and has been well deployed in the history of medicine by, for example, Anna Crozier in her study of the East African Colonial Medical Service. ${ }^{19}$ In this paper, the biographical approach allows us not only to see how the war affected individual careers, but also some of the ways in which it expanded medical knowledge to the wider benefit of humankind. In the interests of extending the sample of lives, a trawl was made of material available for the Lister Institute of Preventive Medicine, with which many of these scientists were associated, and the Journal of Pathology and Bacteriology, organ of the principal specialist society extant at this period. ${ }^{20}$ The Journal is a source of frequently lively obituaries by friends and contemporaries, and although obituaries can be a problematic source, there is an intimacy to many of these tributes which suggests the closeness of the bacteriological community in these years.

The medical doctors and scientists who were drawn away from their usual avocations to engage in war work were variously deployed. Some were already Territorials or members of the Royal Army Medical Corps (RAMC), many more joined the latter sooner or later in the conflict. Many went to serve overseas, and many did not return. Those who were of essential service at home or too old for active service engaged in war-related voluntary service, or in war work on the home front, where they staffed military hospitals and laboratories, engaged in war related research, or - as did a number of women and wives - took over as replacements for

\footnotetext{
${ }^{19}$ Anna Crozier, Practising Colonial Medicine. The Colonial Medical Service in British East Africa (London: I B Tauris, 2007).

20 See Harriette Chick, Margaret Hume, and Marjorie MacFarlane, War on Disease: A History of the Lister Institute (London: Andre Deutsch, 1971), 124-30; Appendix, 231-40.
} 
colleagues or husbands on active service so as to support the home front health care infrastructure as fully as possible. ${ }^{21}$

The sample biographies on which this paper is based suggest six ways in which the war affected the lives of individual doctors and medical scientists. First, there were those whose life paths remained unchanged (if not undisturbed) - those essential to the home services, like William Savage, County Medical Officer for Somerset but also a scientific expert on food poisoning - or those potentially useful, like young James Craigie (b.1899), later distinguished for developing the technique of phage-typing for typhoid, who was studying medicine at St Andrew's when called up, but was promptly sent back to complete his medical degree. ${ }^{22}$ Secondly, there were those who, while remaining in post at home, took on war-related responsibilities, as did William James Howarth, Medical Officer of Health for the City of London, who maintained an efficient service despite the gradual depletion of his staff, but was also a Commissioned Major in the RAMC, became Medical Administrator of the war hospital established at Fishmongers' Hall, and was appointed chief rationing officer for London and the Home Counties when food rationing was introduced in $1916 .{ }^{23}$ Thirdly, there was the group whose research paths were deflected or developed by the war, as happened to Frederick Andrewes, deflected to work on bacterial variation in dysentery and then Salmonella bacteria, and his younger colleague Mervyn Gordon, working on cerebro-spinal fever for the War Office. Fourthly, there were those whose career paths were completely changed by the war; fifthly a small group who served, but whose mental welfare was deeply

\footnotetext{
21 These observations are based on a survey of material printed in Medical Officer over the duration of the war. For medical women's work see also Whitehead, Doctors, 117-19.

22 Sir Christopher Andrewes, 'James Craigie', Biographical Memoirs of Fellows of the Royal Society, 1979, 25, 233-240, 233; Anon, 'Sir William George Savage', BMJ, 1961, i, 113. For medical students and the war see Whitehead, Doctors, 91-106.

23 Anon, 'Death of Dr W. J. Howarth', Medical Officer, 1928, 39, 280.
} 
affected by the fact of war itself or by experiences on active service; and lastly those whose lives and careers ended, as did those of William Sewell, who worked on Salmonella in the Bacteriology and Pathology Departments of Durham University before joining the British Expeditionary Force in August 1914, to fall in action at Thiepval on 1 July 1916; and Armand Rueffer, first Director of the Lister Institute, blown up aboard ship in 1916 while working for the Red Cross in the Eastern Mediterranean. ${ }^{24}$

\section{Laboratories in a Context of War}

In the background to this drama of human lives, the laboratories played a critical, if subordinate, role as the spaces in which these researchers worked and communicated. They were important for sheltering individuals and communities with shared interests, who exchanged ideas, taught others, and were engaged in common projects of furthering knowledge - in this case about bacterial agents and other causes of disease. There were a small number of laboratories working on research into public-health related issues in Britain before the creation of that great engine of public health research, the (Emergency) Public Health Laboratory Service in 1939. The Medical Department of the Local Government Board had sponsored what were termed Auxiliary Scientific Investigations since the early 1870 s, but the Board did not acquire its own laboratory until $1913 .{ }^{25}$ It was only after the creation of the Ministry of Health in 1919 that this laboratory began to function as a research lab, and even then, its scientific personnel consisted of only three people. ${ }^{26}$ More

\footnotetext{
24 'William Tate Sewell', Journal of Pathology and Bacteriology, 1916-17, 21, 112-14; 'Sir Mark Armand Rueffer', Jnl Path. \& Bact. 1916-17, 21, 401-02.

${ }^{25}$ For the auxiliary scientific investigations see Royston Lambert, Sir John Simon, 1816-1904, and English Sanitary Administration (Bristol: McGibbon and Kee, 1965), 314-16, 399-404, 568-69.

${ }^{26}$ See Ministry of Health, Chief Medical Officer's Report (1920), 150-52. The laboratory here referred to is the Bacteriological Laboratory (formerly the Pathology Laboratory); the Ministry also supported
} 
important in relation to research and careers in bacteriology and pathology circa 1900-1920 were the Pathology Department at St Bartholomew's Hospital, where Edward Emmanuel Klein, the so-called father of English bacteriology, was located, and the Lister Institute of Preventive Medicine, a privately run foundation with research laboratories in Chelsea and a laboratory for the production of vaccines and immune sera - products which helped finance the enterprise - at Elstree in Hertfordshire. ${ }^{27}$ The department at St Bartholomew's was long established but had been modernised and dynamised under the professorship of Alfredo Kanthack in the 1890s. ${ }^{28}$ The Lister had come into being as the British Institute for Preventive Medicine in 1896, and until World War II, Bacteriology was the largest of its research departments. ${ }^{29}$ It was a lively and sociable institution, and a mecca for international visitors. ${ }^{30}$ Many of the people who worked at these facilities were also members of the Society for Pathology and Bacteriology.

The Lister and the St Bartholomew's laboratories were, of course, land-based civilian facilities, whose peace-time energies were diverted in the emergency of war. World War I also saw the introduction of a new military facility: the mobile laboratory, designed for service on the battlefield. Microbiology had first been co-opted into regular military service in the Russo-Japanese War of 1904-05 when the Japanese field hospitals were furnished with bacteriological equipment, while the Russians

\footnotetext{
the Government Lymph Establishment, and a small facility attached to the Foods Department in Whitehall.

${ }^{27}$ For the St Bartholomew's laboratory see Keir Waddington, Medical Education at St Bartholomew's Hospital 1123-1945 (Woodbridge: The Boydell Press, 2003), 138-44; F. W. Andrewes, 'The Pathological Department of St. Bartholomew's Hospital', Saint Bartholomew's Hospital Reports, 1898, 34, 193-204; idem, ' The beginnings of bacteriology at Bart's', St Bartholomew's Hospital Journal, 1927-28, 35,100-04,116-17. For the Lister see Chick et al, War on Disease, 131-42.

28 Andrewes, Pathological Department', 196-99; A. A. B., 'Alfredo Atunes Kanthack', St Bart's Hosp. Reps, 1899, 35, 1-11.

${ }^{29}$ Chick et al, War on Disease, 132, 142.

30 Leslie H. Collier, The Lister Institute of Preventive Medicine. A Concise History (London: Lister Institute for Preventive Medicine, 2003), 36-37.
} 
created five special sanitary detachments, each consisting of four bacteriologists and a laboratory stationed on the railway, from which they were to proceed in the event of any epidemic outbreak. ${ }^{31}$ Mobile pack-up laboratories were part of the equipment of the German Army at this time, were incorporated into Turkish and American army arrangements around 1910, and were present in the Austrian Army by $1913 .{ }^{32}$ The first suggestion for a laboratory contained within a 'closed motor vehicle', to march and work with army divisions came from Lyle Cummins of the RAMC in 1912, in an essay concerning the control of typhoid and its carriers in military service. ${ }^{33}$ Such mobile laboratories were implemented in the field from October 1914, each accompanied by a motor cycle with side car, which ferried the Medical Officer in charge when collecting specimens for analysis. ${ }^{34}$ In May 1915, General Headquarters determined on two mobile laboratories per army; by the end of the war a total of 25 mobile laboratories were in service. ${ }^{35}$ While the detection of typhoid carriers formed a significant part of their work, the medicals of the mobile laboratories also engaged in other war-related research, for example into the best treatments for septic wounds, and the discovery of meningococcus carriers. ${ }^{36}$

The mobile laboratories were not the only testimony to the Army's sensitivity to the need to co-opt bacteriology to the task of preserving military manpower wherever possible. When meningitis became problematic among recruits awaiting

\footnotetext{
31 Gray, 'Mobile laboratories', 257-58. See also Sir William G. McPherson, The Russo-Japanese War. Medical and Sanitary Reports from Officers attached to the Japanese Force in the Field (London: HMSO, 1908), 12, 371; Appendix III, 376-77; Appendix X, 381-82. On the achievements of Japanese medical science at this time see Louis L. Seaman, The Real Triumph of Japan: The Conquest of the Silent Foe (New York: Applegate, 1906), 210-32.

32 Gray, 'Mobile laboratories', 258-59.

${ }^{33}$ Major S. L. Cummins, 'The causation and prevention of enteric fever in military services', Journal of the Royal Army Medical Corps, 1913, 21, 39-68, 67 (Parkes Memorial Prize Essay, 1912).

34 The War, 'The Princess Christian', 207.

35 Gray, 'Mobile laboratories', 265.

${ }^{36}$ Casualties of the Medical Service, 'Sydney D. Rowland MA Camb, MRCS, LRCP, Major RAMC', B.M.J., 1917, i, 375-76, 376.
} 
deployment in the early months of the war, War Command established a new laboratory network, devoted to the study and control of the infection, with headquarters at the RAMC College at Millbank. The early wartime investment of funds, energy, and effort in integrating bacteriological research into military strategy is a clear example of the Army's faith in the capacities of the new science of microbiology.

Bacterial Variation and the Challenges of War

On the Home Front the Great War was important in accelerating research into several particular areas of war-related medical science, notably bacterial variation in dysentery, meningitis, and Salmonella. It was on the Home Front that research into broader public health problems could best be done, away from the battlefields. In the early years of bacteriology, beginning with the discoveries of Louis Pasteur and Robert Koch in the late 1870s, and continuing through to around 1900 , the discovery of bacterial agents of specific diseases was a world-wide endeavour. Initially, there was some idea that each disease would have its distinct causal organism, but from the point at which streptococci were discovered to be connected with various morbid conditions in humans, the question of bacterial variation came under discussion. ${ }^{37}$ By the 1890s it was becoming clear that if one pathogenic organism was associated with one particular disease in some cases, whole families of related bacteria also existed, often causing rather different forms or degrees of illness. ${ }^{38}$ Thus the typhoid

\footnotetext{
${ }^{37}$ F. W. Andrewes and T. J. Horder, 'A study of the streptococci pathogenic for man', Lancet, 1906, i, 708-713, 775-782, 852-55, 708. On these debates see Olga Amsterdamska, 'Medical and biological constraints: early research on variation in bacteriology', Social Studies of Science, 1987, 17, 657-87. $38 \mathrm{M}$. H. Gordon, 'Bacillus coli communis: some of its varieties and allies; their relation to the typhoid bacillus', Jnl Path. \& Bact., 1896-97, 4, 488-51, 488.
} 
bacillus was identified between 1880 and 1884 , but by the mid-1890s pathogenic bacteria had been isolated from animals and from human cases of what was known as 'meat poisoning' which were culturally related to the typhoid bacillus. At much the same time it became evident that the streptococci also existed as tribes. By the early 1900s, bacterial variation had become a distinct area of research. Critical to this enterprise was the introduction of serological techniques for analysing bacteria which had been developed in Vienna by Max von Grüber in collaboration with a young English researcher, Herbert Durham. In 1899, Durham published a paper on what would become known as the Salmonella family of bacteria which was a landmark contribution to the study of bacterial variation. ${ }^{39}$ Another gifted young researcher, Mervyn Gordon, located at St Bartholomew's, was also using these techniques to elucidate the relations between various strains of bacteria belonging to the Eserichia coli family, the so-called Gaertner group (Salmonella), the meningococci, the streptococci, and the staphylococci groups. ${ }^{40}$ His identification of three serological types of streptococci, for example, was regarded as the starting point for work continued by Frederick Andrewes, which led eventually to Frederick Griffith of the Ministry of Health laboratory finally defining 27 types of streptococci 14 years later ${ }^{41}$

This early history of bacterial variation fed in to the life stories of several of my protagonists, whose acquired expertise in serology and bacterial classification determined their war work, and in one instance determined a life course. Of the half dozen 'experience categories' previously discussed, it is those in groups three and four - those whose careers were temporarily deflected, and those whose careers

\footnotetext{
${ }^{39}$ Herbert E. Durham, 'The present knowledge of outbreaks due to meat poisoning', B.M.J., 1898, ii, 1797-801.

40 Lawrence P. Garrod, 'Mervyn Henry Gordon', Obituary Notices of Fellows of the Royal Society, 1954, 9, 153-63, 160.

41 Ibid, 155.
} 
were completely re-directed - that hold most immediate interest. Let us begin with the deflected, and with Andrewes and Gordon, since they were involved at a senior level in the meningitis research project run from Millbank, and their patronage is evident in at least some of the appointments of scientific staff made to the project. Although both were to return to earlier interests after the war, the meningitis project based in their expertise was the occasion for transforming the careers of a number of its junior officers. The meningitis project forms a jumping off point into the serious career translations experienced by RAMC officers.

Lives, Laboratories, and the Fortunes of War

Frederick Andrewes spent most of his career, from his appointment in 1897 to retirement in 1927, as professor of pathology at St Bartholomew's, although he was briefly associated with the Lister in 1917. Keenly interested in 'the hygienic aspects of bacteriology', he acted as 'sanitary officer' to his hospital for many years, even investigating local outbreaks of food poisoning. ${ }^{42}$ He was also interested in the bacteriology of milk, in the bacterial flora of public spaces such as Oxford Street and Hyde Park, in devising methods for identifying pathogenic forms of bacteria, and in the relationship between the bacteria of sewage and those found in sewer air. In 1905-06, together with Gordon, he reported on the biochemical characters of various streptococci to the Local Government Board. ${ }^{43}$ It was Gordon's use of the agglutination and absorption tests in identifying three serological types of

\footnotetext{
42 A. E. B., 'Frederick William Andrewes', Jnl Path. \& Bact, 1932, 35 ii, 639-46, 642; see also M.H.G. 'Frederick William Andrewes', Obit. Not. FRS, 1932-35, 1, 37-44; Lancet, 1899, i, 8.

${ }^{43}$ F. W. Andrewes and M. H. Gordon, 'Report on biological characters of the staphylococci pathogenic for man', Medical Officer's Annual Report, Local Government Board, British Parliamentary Papers, 1907 xxv, 435-68.
} 
streptococci that was the starting point for the work which Andrewes and T. J. Horder did in analysing and classifying some 1200 strains of streptococci into 6 groups perhaps the earliest exercise in establishing classification and nomenclature for a family of bacteria. Andrewes and Horder made it clear that intermediate forms of streptococci were common, and they considered the whole 'company' of streptococci to be 'a dominant group in active evolution in which specific segregation is by no means complete or sharp - a district, as they put it, in which the mountain peaks are separated by shallow valleys'. ${ }^{44}$

The project of identifying the streptococci provided a model for efforts at understanding and classifying other families of bacteria which became important during the Great War. Andrewes joined the RAMC in 1914 as a bacteriologist, initially working on the meningococci, since unprecedented outbreaks of meningitis were occurring in the camps of young army recruits waiting their posting abroad. British troops were well protected against typhoid, and later paratyphoid, by vaccination, but as the Army became entrenched on the Western Front, lesser intestinal infections became rife. Andrewes turned his attention to Flexner group dysentery bacilli, and later to the Salmonella, continuing to use the serological methods which had proved so effective with the streptococci. ${ }^{45}$ While Andrewes was to publish important work on the Salmonella after the war, he then returned to the study of the haemolytic streptococci, remaining alert to developments around his other bacterial interests. ${ }^{46}$ His work on the identification of Salmonella by serological

\footnotetext{
44 A. E. B., 'Andrewes', 643.

45 Ibid, 644-45; see also M.H.G., 'Andrewes', 40-41.

46 M.H.G. 'Andrewes', 41.
} 
methods proved foundational to a major scientific enterprise that developed during the interwar period. ${ }^{47}$

Gordon's war work was, if anything, both less and more of a departure from his usual activities than Andrewes'. During a health alert generated by outbreaks of meningitis in Central Europe and America around 1904, Gordon had been commissioned by the Local Government Board to investigate the causal organism of cerebrospinal meningitis, but thereafter worked on other topics. ${ }^{48}$ In 1912-13 he was investigating Alexandre Besredka's sensitised vaccine for the prevention of anaphylactic shock, and in 1913-14 he turned his attention to mumps. ${ }^{49}$ The alarming outbreaks of meningitis among young recruits in overcrowded barracks, which began occurring in the autumn/winter of $1914 / 15$, returned his attention to the meningococcus, and involved him in what seems to have been a unique war-time project of concentrated laboratory research, for which he was the expert teamleader. By early 1915 meningitis cases, though not epidemic, were occurring over a wide area, and in February the War Office took action. Gordon was recruited to the RAMC as Honorary Lieutenant-Colonel, and given full authority 'in everything pertaining to the investigation and control of this infection' ${ }^{50}$ This was a major enterprise. A central, fully staffed, laboratory was set up under Gordon's direction at the Royal Army Medical College, Millbank, where media for cultivating the meningococcus were prepared for despatch to fifty different bacteriological

\footnotetext{
${ }^{47} \mathrm{~F}$. W. Andrewes, 'Studies in group agglutination. I. The Salmonella group and its antigenic structure', Jnl Path. \& Bact., 1922, 25, 505-21. For this enterprise see Anne Hardy, Salmonella Infections, Networks of Knowledge, and Public Health in Britain, 1880-1975 (Oxford: Oxford University Press, 2015), 119-29, 138-49.

${ }^{48}$ M. H. Gordon, Report to the Local Government Board on the Micrococcus of Epidemic Cerebrospinal Meningitis, with Special Reference to its Presence in the Upper Respiratory Tract (London: HMSO, 1907).

${ }^{49}$ Garrod, 'Gordon', 161.

50 Ibid, 155-56. On these outbreaks see Surgeon-Colonel R. J. Reece, 'Notes on the prevalence of cerebrospinal fever . . . , JRAMC, 1915, 23, 555-68.
} 
laboratories in the several commands, and to which bacteriologists with no previous experience of meningitis were sent for instruction. ${ }^{51}$ At least twenty-odd officers were variously involved in this enterprise under Gordon's direction.

The elaborate structure of prevention developed by the army to meet the meningitis emergency not only underscores Mark Harrison's designation of this as 'The Medical War', but also testifies to the degree to which bacteriology was now regarded as a serious science. Across the country, existing bacteriological laboratory facilities were commandeered for work on meningitis from universities, counties, and municipalities, and some private facilities were also utilised; this work was not uncompensated - most of the professional staffs received grants in aid from the Medical Research Committee (MRC). Where civil laboratories were not available, existing military hospital laboratories were adapted or military laboratories were newly created. In all, some forty laboratories were linked into this network in England and Wales, with others in Scotland and Ireland. ${ }^{52}$ Finally, to meet any emergencies, a mobile bacteriological laboratory on the field model was fitted out, and placed in the charge of Captain T. G. M. Hine of the Millbank staff, with a specially appointed, dedicated, laboratory assistant. This travelling laboratory serviced outbreaks where local staff were insufficient to deal with the situation, and also on occasion helped to confirm results. ${ }^{53}$ Nor was the control of outbreaks the only object of this exercise:

\footnotetext{
51 Reece, 'Notes', 562.

52 Twenty-five of these are listed in Medical Research Committee, 'Report to the Special Advisory Committee upon bacteriological studies on cerebro-spinal fever during the epidemic of 1915', Special Report Series, 1916, 2, 6.

53 Ibid., 562-63; see also Major T. G. M. Hine, 'Report on the supply department of the Central Cerebrospinal Fever Laboratory for the period February 19th, 1915 , to August 1916', Special Report Series, 1916, 3, 91-99. This paper gives a detailed description of the mobile laboratory's fittings, with photographs of its exterior and interior, which may be compared with those of the Princess Christian field laboratory (note 11 above).
} 
there was also a substantial research output, published under the auspices of both the MRC and of the RAMC. ${ }^{54}$

Military service with the meningitis control effort also offers examples for the life experiences of the medical community involved in the war effort. Not all the twenty-odd medical officers who published on their meningitis work with the MRC or the RAMC during these years can be traced, but several biographies are available, showing variable career progressions. Gordon himself worked with the meningococcus for the duration of the war, and for several years thereafter, even as his interests diversified with peace-time. He returned to St Bartholomew's, where he remained for the rest of his career, moving on from the bacteria to study viruses in the 1920s. Among the members of the cerebrospinal team, Martin Flack, Medical Officer in Charge of the London District cerebrospinal fever laboratory from 1915-17, was a physiologist who seems to have continued working with Sir Leonard Hill during these years. ${ }^{55}$ While still with the RAMC, he was recruited to take charge of the new department of medical research which the Air Ministry was setting up, and remained in that service for the rest of his career. ${ }^{56}$ James Alison Glover, who as a medical student had both fought and worked in the Boer War before becoming a general practitioner, joined the RAMC at once in August 1914. He served with the Malta Command, and at the Battle of the Somme, and succeeded Flack as Medical Officer

\footnotetext{
54 See for example Medical Research Council, 'Cerebrospinal Fever. Studies in the Bacteriology, Preventive Control and Specific Treatment of Cerebrospinal Fever among the Military Forces, 191519', Special Report Series, 1920, 50; M. H. Gordon and E. G. Murray, 'Identification of the meningococcus', JRAMC, 1915, 25, 411-23; Captain Arthur W.M. Ellis, 'A classification of meningococci based on group agglutination obtained with monovalent immune rabbit serum,' ibid., 1955, 26, 64-75; Captain Leonard Colebrook and Lieutenant Harold H. Tanner, 'Meningococcus carriers', ibid., 76-88. Publications on meningitis under both heads continued until 1920.

${ }_{55}$ Captain Martin Flack, 'Report on cerebrospinal fever in the London district, December 1915, to July 1916', JRAMC, 1917, 28, 113-45.

${ }^{56}$ Anon, 'Group Captain Martin Flack, C. B. E.', B.M.J., 1931, ii, 402. This obituary does not mention his RAMC service but see Medical Research Council, 'Cerebrospinal fever', 10.
} 
in charge of the London District laboratory in 1917. That appointment changed his life. His work on meningitis and its prevention earned him an O.B.E: his observation that the 'spacing-out' of beds in barrack sleeping quarters was critical to preventing infection had provided the key to the problem. As Gordon told him, Glover had been 'a good friend to the private soldier'. ${ }^{57}$ In 1920 he was appointed to a medical officer post in the new Ministry of Health. He became the senior medical officer in the Ministry of Education in 1934, and was brought out of retirement in 1941 to serve again in the Ministry of Health for the duration of World War II. ${ }^{58}$

Flack and Glover are only two examples of those whose war-time experiences proved life-changing. Several more scientists with experiences in areas other than cerebrospinal meningitis went on to become significant figures in their new fields. A leading figure in the interwar pursuit of the Salmonella was Philip Bruce White, who was a classic example of a scientist on whose career the war wrought an almost complete transformation. Bruce White had studied botany and zoology at university, and completed his degree in 1915, intending to study medicine. He was, however, determined to put his scientific training into the war effort, although an accidentally mutilated right hand made him unfit for active service. Family connections arranged for him to spend a few months at the Lister Institute under Joseph Arkwright and Harrie Schütze who were then working on the Salmonella using serological methods, where Bruce White acquired a sound knowledge of these techniques. ${ }^{59}$ Baulked of the chance to serve with a British Red Cross mobile laboratory in Serbia by the

\footnotetext{
${ }^{57}$ Anon, 'Glover, James Alison', Munk's Roll, 1965, 152-55, 153. See Captain J. A. Glover, "Spacing out" in the prevention of military epidemics of cerebro-spinal fever', B.M.J., 1918, ii, 509-12. 58 Anon, 'Glover', 152-55.

59 Wilson Smith, 'Philip Bruce White', Obit. Not. FRS, 1950-51, 7, 279-92, 282. Wilson Smith did not specify the 'friends' who made this possible, but Bruce White was well connected. His father was the first professor of zoology at the University College of North Wales, and J. C. Philip, eminent physical chemist, and Sir Robert Philip, the authority on tuberculosis, were near relatives: see Percival Hartley, 'Philip Bruce White', Jnl Path. and Bact., 1950, 62, 468-77.
} 
enemy's capture of the unit, Bruce White worked in the school of pathology at Trinity College Dublin, and later as a civilian pathologist in the Army Medical Department's laboratory at Tidworth. These experiences turned him into 'a master of technique'. 60 Some uncertain years followed the end of the war, but in 1921 Bruce White's luck changed. In that year, the new Ministry of Health and the MRC jointly sponsored a research project into the nature and character of food poisoning outbreaks in England and Wales. The principal researcher was William Savage, County MO for Somerset, who had worked extensively on food poisoning before the war, and Bruce White was appointed as the project's laboratory technician. This was the turning point of his life. He dedicated himself to bacteriology, and especially the pursuit of Salmonella, 'without further remission'. ${ }^{61}$ Bruce White's work on this project between 1921 and 1927 built on that of Andrewes, Arkwright, and Schütze, and was the basis of the definitive Kauffmann-White classification scheme for the Salmonella family, approved by the International Society for Microbiology in $1934 .^{62}$

Two other scientists whose work was closely associated with Salmonella were also researchers whose career trajectories were altered by the war. Arthur Felix, Austrian by birth and trained as a chemist, found himself, because of his laboratory experience, recruited to serve with Edmund Weil in the No 5 Austrian Army mobile epidemiology laboratory in 1914. This laboratory was primarily interested in typhus, and it was here that Felix and Weil developed the first diagnostic test for the disease (the Weil-Felix reaction). ${ }^{63}$ This in turn led them to the discovery of the $\mathrm{H}$ and $\mathrm{O}$ antigens of the Proteus and enteric groups of bacteria. Following Weil's death in

\footnotetext{
60 Percival Hartley, 'Philip Bruce White', Jnl Path. \& Bact., 1950, 62, 468-81, 470.

61 Smith, 'Bruce White', 282.

62 Salmonella Sub-committee, 'The genus Salmonella Lignières 1900', Journal of Hygiene, 1934, 34, 335-36.

63 James Craigie, 'Arthur Felix', Biog. Mem. FRS, 1957, 3, 53-79, 53.
} 
1922 and his own emigration to Palestine, Felix continued to work on the serodiagnosis of typhoid, and in 1924 published his classic paper on qualitative receptor analysis and its application to typhoid, which attracted the attention of, among others, Joseph Arkwright and Charles Ledingham at the Lister Institute. ${ }^{64}$ Arkwright, who had worked on bacterial variation before 1914, had devoted the war years to trench fever and typhus. Ledingham's pre-war interests were phagocytosis and immunity; post-war he turned to bacteriological subjects - dysentery, enteric, trench fever, typhus, tularaemia, and experimental purpurea in birds and reptiles. ${ }^{65}$ The correspondence which Arkwright and Ledingham initiated with Felix led him to visit the Lister in 1927. Impressed by the sympathetic character of the Institute (it was a highly congenial place to work) and by the quality of its laboratory facilities compared to what was available in Palestine, Felix asked to come to work there. This was subsequently arranged; initially temporary, he was appointed to the staff of the Bacteriology Department in $1931 .{ }^{66}$ In London, Felix continued to work on enteric infections, and in 1934, with his co-worker Margaret Pitt, he discovered the Viantigen of typhoid, which in turn enabled the epidemiologically important discovery of typhoid Vi-antigen phage-typing by James Craigie and Chun Hui Yen in 1939. ${ }^{67}$ Felix's wartime experience thus transformed him from a chemist into a bacteriologist, and translated him from Austria via Palestine to England, where he ended his career as Director of the Public Health Laboratory Service's Central Enteric Reference

\footnotetext{
${ }^{64}$ Arthur Felix, 'The qualitative receptor analysis in its application to typhoid', Journal of Immunology, $1924,9,115-92$.

${ }^{65}$ C. J. Martin, 'Joseph Arthur Arkwright', Obit. Not. FRS, 1945-48, 5, 127-13; S. P. Beddoes, 'John Charles Grant Ledingham', ibid., 325-40.

${ }^{66}$ Craigie, 'Felix', pp. 55-6.

${ }^{67}$ James Craigie and C. H. Yen, 'The demonstration of types of $B$. typhosus by means of preparation of type 2 Vi phage.I. The principle and technique', Canadian Public Health Journal, 1938, 29, 448-83; idem, 'The demonstration of types of $B$. typhosus by means of preparation of type 2 Vi phage. 2 . The stability and significance of Vi form types of B. typhosus', ibid., 483-96.
} 
Laboratory ${ }^{68}$ Felix's story indicates that German scientists similarly underwent career-transforming experiences during the war; he is included here because of his eventual standing in the British - and indeed the global - microbiological community.

A third scientist whose wartime experiences changed his career path and led to involvement with Salmonella would not work on them directly, but used Salmonella typhimurium (mouse typhoid) as a research tool. This was William Whiteman Carlton Topley, Professor of Bacteriology at the London School of Hygiene and Tropical Medicine (LSHTM) from 1927 to 1944. Topley was medically qualified, and before the war worked in the pathology department at Charing Cross Hospital. ${ }^{69}$ His publications of this period are entirely pathological, as in his study of red cell fragility in jaundice. ${ }^{70}$ During the war he served for part of the time with a mobile bacteriological unit on the Eastern Front, and observed the great Serbian typhus epidemic of 1915 at first hand. ${ }^{71}$ This roused his interest in epidemiology, and on returning to civilian life at Charing Cross, he began to explore the existing literature on epidemiology. He found it profoundly unsatisfactory..$^{72}$ The works of the then best-regarded writers on epidemiology were based in the recorded observations of interested local medical men, many of which dated from the days before bacteriology. ${ }^{73}$ Topley's approach was instead practical and analytical, informed by his laboratory training. As noted by his obituary writer, 'a man with a lively faith in the

\footnotetext{
68 Craigie, 'Felix', 56.

${ }^{69}$ Major Greenwood, 'William Whiteman Carlton Topley', Obit. Not. FRS, 1942-44, 4, 699-712.

70 W.W.C. Topley, 'Red cell fragility in jaundice', Lancet, 1914, i, 715-16.

71 W W. C. Topley, 'A report on the bacteriological investigation of typhus during the Serbian typhus epidemic of 1915', JRAMC, 1915, 25, 215-18. On this epidemic see William Hunter, 'The Serbian epidemics of typhus and relapsing fever in 1915..., Proceedings of the Royal Society of Medicine, 1920, 13, 29-158; James Berry et al, The History of a Red Cross Unit in Serbia (London: J \& A Churchill, 1916); Richard P. Strong et al, Typhus Fever with Particular Reference to the Serbian Epidemic (Cambridge, Mass: American Red Cross at Harvard University Press, 1920).

72 Greenwood, 'Topley', 707.

73 These included classic works by August Hirsch, Charles Creighton, and John Brownlee.
} 
experimental method might expect in the clearer atmosphere of the laboratory to replace the confused arithmetic of deceased parish officers by precise records of accurate, defined and carefully observed infections' ${ }^{74}$ Topley conceived the notion of experimental epidemiology, of studying the behaviour of infections in herds of laboratory mice. Invited to give the Goulstonian Lectures for 1919, he took the spread of bacterial infections as his subject. In his first lecture he set out three fundamental problems in epidemiology: the interval between epidemics or pandemics; the awakening of the infectious agent into activity; and the sequence of events in the epidemic itself. In his final lecture he described his own first contribution to experimental epidemiology - a study of the changes in pathogenicity in strains of Salmonella enteritidis danysz. ${ }^{75}$ In effect, this was the draft programme for the work which absorbed him for most of the rest of his life, first as Professor of Bacteriology at Manchester (1922-27), and from 1927 to 1944 at the LSHTM. For Topley, no less than for Felix, the Great War re-directed the trajectory of his career.

There are further examples of changed careers paths, but one of the most dramatic was that of John Smith Knox Boyd, scion of an ancient Scottish lowland clan, who graduated from Glasgow University in 1913, intending eventually to become a general practitioner in his home country. He spent the year 1913-14 as houseman to John Cowan, a leading Scots cardiologist, and in April 1914, 'following the custom of the time', took a position as ship's surgeon, meaning to relax for six months before returning to Glasgow Infirmary as a house surgeon. He arrived home on 26 July, 'with no real idea of the storm that was brewing'. ${ }^{76}$ (This was a far from uncommon position: the physiologist Henry Dale recorded that the outbreak of war

\footnotetext{
74 Greenwood, 'Topley', 702.

75 Ibid; W. W. C. Topley, 'The spread of bacterial infection', Lancet, 1921, ii, 1-5, 45-49, 91-96.

76 L. G. Goodwin, 'John Smith Knox Boyd', Biog. Mem. FRS, 1982, 28, 27-57, 29. 
'fell like a bomb and almost without warning, on the plans and programmes of those of us who were engaged in scientific researches of almost any kind, especially those who were still of military age'. ${ }^{77}$ ) When war was declared, Boyd applied for a commission in the RAMC, and in December arrived in France with a Field Ambulance, and went straight to the Ypres salient. Eighteen months later, in the summer of 1916, he was appointed Medical Officer to the Divisional Engineers, and with them trekked widely through Macedonia, encountering bacillary dysentery for the first time. He was then selected for bacteriological training, and by spring 1917 was on the Vardar Front, Macedonia, in charge of a mobile laboratory. The local strain of malaria was very severe, and here Boyd acquired 'a unique clinical experience of [both] malaria and bacillary dysentery'. ${ }^{78}$ His experiences in Macedonia caused Boyd to set aside all plans for a return to Scotland as a physician. ${ }^{79} \mathrm{He}$ had become hooked on tropical medicine, and at the end of the war applied for a regular commission in the RAMC. He thereafter pursued a distinguished career between India and the RAMC College at Millbank; did important research on bacillary dysentery; served in the Middle East during World War II; and in 1946, longing to get back to research, accepted the Directorship of the Wellcome Tropical Research Laboratories, where he conducted his own research into the relationship between bacteria and bacteriophages, and supervised others' research proceedings for the next nine years. ${ }^{80} \mathrm{He}$ was elected a Fellow of the Royal Society in 1951 and knighted in 1958. Not all career shifters reached these heights of

\footnotetext{
77 Henry H. Dale, 'Percival Hartley', Biog. Mem. FRS, 1958, 4, 81-100, 82.

78 Goodwin, 'Boyd', 308. For conditions in Macedonia see Arthur G. Phear, 'Medical experiences in Macedonia and the Caucasus', Proc. Roy. Soc. Med., 1919, 13, Part II, General Section, 57-100. 79 Anon, Brigadier John Smith Knox Boyd', Munk's Roll, 7, 57-58.

80 Ibid, 58.
} 
recognition, but, like Boyd, Bruce White, Felix, and Topley all became Fellows of the Royal Society. ${ }^{81}$

Women scientists experienced similar patterns of deflection and career redirection to their male colleagues. A difficulty here is that the first decade or so of the twentieth century was still a time when very few women were being recruited into medicine and science. Many went unsung - more so than their male contemporaries of similar status. Women featured increasingly prominently among microbiologists from the 1920s, yet for many decades they were rarely accorded the recognition of obituaries by journal editors. The women important to the Salmonella story fall into this category, perhaps because they were considered rather as technicians or administrators. ${ }^{82}$ But some important examples reached the records in other fields of research. In 1914, there were just two women scientists employed at the Lister Institute, Harriette Chick and Muriel Robertson, but they both went on to highly distinguished careers. Chick became a Dame of the British Empire in 1949 for her work in nutrition science; Robertson was elected a Fellow of the Royal Society in 1947 for key discoveries on the life cycle of the trypanosomes. Both worked at the Lister throughout the Great War; Chick's career trajectory changed as a result; Robertson's was temporarily deflected.

Harriette Chick trained at University College London and did a PhD in bacteriology. She started work at the Lister in 1905 as assistant to the then director, Charles Martin - the first woman to be employed there. ${ }^{83}$ She began by working on

\footnotetext{
${ }^{81}$ One career shifter who did not reach this eminence was Guy Wyon, a pre-war GP who became a university lecturer in bacteriology after the war: 'Guy Alfred Wyon', Jnl Path. \& Bact., 1924, 26, 46466.

${ }^{82}$ On laboratory technicians, and the position of women, see E. M. Tansey, 'Keeping the culture alive: The laboratory technician in mid-twentieth-century British medical research', Notes and Records of the Royal Society, 2008, 62, 77-95.

${ }^{83}$ A. M. Copping, 'Dame Harriette Chick', British Journal of Nutrition, 1978, 39, 3-4.
} 
various disinfectants, then on the rat fleas that transmit bubonic plague. At the outbreak of war, the male Lister staff volunteered their services to the RAMC. Within a few months almost all the male scientific staff, students, and guest researchers had been recruited to serve, and fifteen of the junior staff had also volunteered. ${ }^{84}$ Chick and Muriel Robertson, who had been recruited in 1909, and most remaining staff, were also delegated to war service: their energies were devoted to the production of various vaccines and sera. Chick and Robertson were transferred to the Lister laboratories at Elstree to test and bottle tetanus anti-toxin serum for the Army. The pressures of war meant that Chick was soon moved back to Chelsea to prepare agglutinating sera for the diagnosis of typhoid, paratyphoid, and dysentery, then rife among troops in Flanders and the Middle East. ${ }^{85}$

In 1916, however, Charles Martin, serving with the Medical Corps of the Australian Army in the Middle East, was discovering cases of both beriberi and scurvy among the troops in his care, which he believed to be caused by army rations consisting solely of tinned meat, bread and biscuit made from white flour, and jam. ${ }^{86}$ He wrote to Chick, asking her to find some foodstuffs that might prevent beri-beri among the troops ${ }^{87}$ (Scurvy was known to be curable by the administration of citrus juice.) Many experiments followed, until Chick found that both dried eggs and dried yeast were useful. Work on nutritional problems continued until the end of the war, only for peace to bring serious food shortages in many parts of Europe. In particular,

\footnotetext{
${ }^{84}$ Chick et al, War on Disease, 124.

85 Ibid.

86 Ibid., 126.

87 Copping, 'Chick', 3 . The closeness of the relationship between Chick and Martin (who was happily married) is evident from the correspondence cited in Martin Gibbs, Charles Martin: His Life and Letters (London: Martin Gibbs, 2011). For other military research on the problem of beri-beri see Mark Harrison, 'The fight against disease in the Mesopotamian Campaign', in Hugh Cecil and Peter H. Liddle eds, Facing Armageddon: The First Wold War Experienced (London: Leo Cooper, 1996), 47589, 480-83.
} 
reports came from Austria of rickets in children and bone diseases in adults. Chick and a small team were dispatched to Vienna to investigate, and by 1922 had established deficiency of vitamin D as the cause, and cod-liver oil and sunshine as remedies. ${ }^{88}$ By the time Chick returned to England, her interests had transferred to nutrition science, and remained there for the rest of her career. Her later interests focused on vitamin $B$, the nutritive value of cereals, the effects of modern milling processes on wheat grain, and the comparative values of brown and white bread. With war again on the horizon, these studies proved important in the planning of the World War II National Loaf, and a great deal more work on bread and flour was undertaken during World War II, as well as investigation into the nutritive value of potatoes, and other aspects of wartime food problems. ${ }^{89}$ Martin's 1916 request not only re-shaped Chick's career, but contributed to a future war effort. It also influenced the future of nutritional science for, as one obituary writer noted, Chick 'carried the attachment to fundamental research that opened channels for so much new knowledge' - a contribution that made the Nutrition Society duly proud of this one of its founders. ${ }^{90}$

Muriel Robertson's career, by contrast, returned to its pre-war focus. Robertson had been educated at Glasgow, obtaining her MA in 1905. While still an undergraduate, she began work on the life cycles of the protozoa. She then worked in Germany, studying the protozoan parasite Pseudospora volvocis, and in Ceylon (modern Sri Lanka) working on trypanosome infections in reptiles. She came to the Lister as assistant to E. A. Minchin, the Professor of Pathology, and became a

\footnotetext{
88 See Kenneth J. Carpenter, 'Harriette Chick and the problem of rickets', Journal of the History of Nutrition, 2008, 138, 827-32.

${ }^{89}$ Copping, 'Chick', 3-4.

90 lbid, 4.
} 
member of staff in 1910. From 1911 to 1914 she was in the Uganda Protectorate, working on African trypanosomiasis. Returning to the Lister, she was asked by Joseph Arkwright to take over the work on the bacterial causes of gas gangrene which he had begun before being posted to Malta by the RAMC in $1915 .{ }^{91}$ The aim of this research was to produce an antitoxin treatment for the condition, but this was only achieved at the end of the war. After the war Robertson returned to the trypanosomes, making key discoveries about their life cycle, and she continued her work on protozoa. Her extensive researches in protozoology, the anaerobic bacteria of war wounds, and, in her later career, immunology, are examined in great detail in the lengthy Royal Society obituary by Ann Bishop and Ashley Miles. ${ }^{92}$ Robertson's absorption with the protozoa was not absolute. She kept her finger in the bacteriological pie, dipping in from time to time to refine her war-time investigations. In 1939 she returned to the gas gangrene problem with the assistance of a young veterinarian, with the aim of providing safe vaccines against the disease. ${ }^{93}$

For both men and women, these two career trajectories, of a life course diverted and a life's work temporarily deflected, tell us something of scientific flexibility, of the ideals of service to one's country, of the solid science that emerged from these war-related efforts, and how the pull of individual scientific interests directed individual careers. So far, they have told us little of the pity of war. But there are two life stories that show us more of the emotional pressures which even noncombatant individuals could suffer during that period of terrible conflict. Arthur Edwin Boycott and Major Sydney Domville Rowland were near contemporaries, Boycott

\footnotetext{
91 Martin, 'Arkwright', 133; see also Chick et al, War, 125-26.

92 Ann Bishop and Ashley Miles, 'Muriel Robertson', Biog. Mem. FRS, 1974, 20, 317-47, 322-40.

93 Ibid, 321.
} 
being 37 and Rowland 42 at the outbreak of war. ${ }^{94}$ Boycott survived the war, Rowland did not. Both were qualified in medicine, and on qualifying both went straight into bacteriological research at the Lister, where Rowland remained, while Boycott's career took him to Guy's Hospital with the Gordon Lectureship, then to Manchester as Professor of Pathology, and finally to University College London, again as Professor of Pathology, in 1914. Their tragedies were not those of the shellshocked, of those inflicting and or witnessing the infliction of terrible damage on other human beings; they did not collapse with delusions of being mined by sappers when under mental stress in later life, as did Dorothy Sayers' fictional detective Lord Peter Wimsey, nor were they haunted by ghosts of dead friends and tormented by the misguided interventions of doctors, such as led Virginia Woolf's wretched Septimus Warren Smith to hurl himself from a window to be impaled on the area railings below. ${ }^{95}$ Theirs were subtler forms of distress, and may tell us something about the rise in death-rates among the older survivors of the Great War (especially women) which was recorded in the early years of World War II. ${ }^{96}$

Arthur Boycott, raised in a clerical household in Hereford, had 'never believed that a European war was even a possibility', and he disliked all thought or talk of war intensely. ${ }^{97}$ His somewhat chequered early career path led him from working on ankylostomiasis and later Caisson disease at the Lister (1904-07), to Guy's Hospital where he did some of his best work, and to the professorship of pathology at

\footnotetext{
${ }^{94}$ C. J. Martin, 'Arthur Edwin Boycott, Obit. Not. FRS, 1936-38, 2, 561-71; Anon, 'Major Sydney Domville Rowland', Jnl Path. \& Bact., 1916-17, 2, 453-55.

95 See e.g. Dorothy L. Sayers, Whose Body (London: New English Library, 1970), 124; idem, Busman's Honeymoon (London: New English Library, 1974), 394. Virginia Woolf, Mrs Dalloway (London: Penguin Books, 1992), 163-64. See also Wyatt Bonikowski, Shell Shock and the Modernist Imagination: The Death Drive in Post-World War I British Fiction (London: Penguin Books, 2000), 163-64. [Reissued Farnham: Ashgate, 2013]

${ }^{96}$ Ministry of Health, Chief Medical Officer, Report for 1939-45 (London: HMSO, 1946), Table 4.1, 260.

${ }_{97}$ Martin, 'Boycott', 564.
} 
Manchester in November 1912. However, he disagreed with the university policy which decreed that clinical hospital work should be done alongside research and teaching, and moved to UCL in 1914. August 1914 came as a dreadful shock to him, and in Charles Martin's view he never recovered from that shock. None the less, he abandoned his own scientific work to take up that which younger colleagues absorbed into the army had left unfinished. He served on the Health of Munitions Workers Committee, and later on the Chemical Warfare Medical Committees. He was intensely unhappy, finding himself out of sympathy with most of his friends. Yet he joined the RAMC in 1917 to serve at the experimental station at Porton Down, investigating the physiological action of poison gases used or likely to be used by the combatants. According to Charles Martin, the scientific interest of this work somewhat mitigated the misery he suffered when thinking of the uses to which it would be put. ${ }^{98}$ Returning to University College London after the war, his research increasingly came to focus, according to Charles Martin, on the zoological and genetic characteristics of snails. ${ }^{99}$ The retreat to natural history was not complete, however. Boycott continued to serve his community, as a member of the governing body of the Lister, as a member of the Medical Research Council (1922-35), and as editor-in-chief of the Journal of Pathology and Bacteriology (1923-33). He also worked on blood production with C. L. Oakley, retiring due to ill health in $1935 .{ }^{100}$

In sharp contrast to Boycott, Sydney Rowland joined the RAMC soon after the outbreak of war. Educated at Cambridge (Natural Science) and St Bartholomew's, clinical medicine never appealed to him. His career after qualifying was 'somewhat assorted', until he landed a post at the Lister in 1898. His deep interest in the

\footnotetext{
98 Ibid.

99 Ibid.

${ }^{100}$ Richard R. Trail, 'Arthur Edwin Boycott', Munks Roll, V, 45.
} 
technical aspects of medical problems led him to become a microscopist, with a command of microscopical technique unequalled by most other British pathologists. He was seconded to work with the Plague Commission in India in 1905. On his return to England he set about improving techniques of prophylactic inoculation against plague, publishing a number of papers on the topic between 1909 and 1914. ${ }^{101}$ When the War Office in 1914 asked the Lister for staff to serve with a mobile laboratory on the Cummins model, Charles Martin chose Rowland for the job. ${ }^{102}$ Rowland seems to have been thrilled. He had seen just the vehicle suited to the job (a unique custom-made luxury Austin motor caravan) at the Manchester Motor Show in February that year, and having acquired the vehicle, zestfully fitted out what was the first mobile laboratory for service abroad. He converted the motorcaravan himself, taking a delighted relish 'in desecrating the sybaritic vehicle with laboratory fittings'. ${ }^{103}$ Arriving in France with his servant Bracy in October 1914, he returned home for a short leave in January 1916 a changed man: 'older, thin and worn, not so fond of talk, troubled how the world was to be put straight again'. ${ }^{104} \mathrm{He}$ went back to France to work on wound infections, and died of cerebro-spinal meningitis there in March 1917.

The personal tragedies of Boycott and Rowland illustrate the emotional stress of war on non-combatant scientists, especially perhaps, in Boycott's retreat into frog genetics and Rowland's exchange of zest for trouble. Yet both followed their war work through to the end, no doubt with the grim stoicism which characterises the

\footnotetext{
${ }^{101}$ C.J.M, 'Died on Service. Sydney D. Rowland', B.M.J., 1917, I, 375-76.

102 Gray, 'Mobile laboratories', 203.

103 Gray, 'Mobile laboratories', 63; quotation from Anon, 'Rowland', 455. This vehicle served as a model for the subsequent specially commissioned vehicles: C. J. M., 'Rowland', 376.

104 Anon, 'Rowland', 455.
} 
lived experience of war for so many. ${ }^{105}$ Both were exposed to the realities of war in ways which most of their colleagues employed in the laboratories at home were not, but there is little doubt that the worries of war also exercised the bacteriologists working on the Home Front. It may be that they found consolation and compensation - even pride - in their research undertakings for the armed forces. The tone of scientific comradeship apparent in many of the publications resulting from the meningitis project suggests a co-operative culture of laboratory practice which is not evident in peace-time publications. ${ }^{106}$

The Meningitis Challenge, 1915-18

The meningitis project stands as a classic example of collaborative scientific enterprise, involving as it did many laboratories and many medical personnel, who clearly established a collegial and unified approach to their work. This collegiality can be seen in many of the journal articles which came out of this project, published not only in the Journal of the Royal Army Medical Corps, but also in the Journal of Hygiene, the British Medical Journal, and The Lancet. Clearly the project was recognised as an opportunity for the RAMC laboratory network to establish a scientific reputation for quality research in the medical community, and to justify noncombatant status to the wider community. Thus in a note on the meningococcus, Gordon and his colleague E. G. Murray thanked Joseph Arkwright (Lister Institute), Captain Gaskell (First Eastern General Hospital), Dr O’Brien (Brockwell Hall), Lieutenant McMahon (York), Lieutenant Compton (Weymouth), Louis Martin of the

\footnotetext{
105 See, for example, Diana Athill, Alive, Alive Oh! (London: Granta, 2015), 29-30.

${ }^{106}$ A search for archive footprint for this project was unprofitable. Mervyn Gordon's papers (microfilm, Devon Archives Service) do not refer to it, and the two volumes in the Wellcome Library RAMC Collection, 'Cerebrospinal meningitis 1914-1918', are made up of typescript copies of printed material, journal pages, and offprints dealing with all aspects of the meningitis problem, prepared for the compilers of the Medical History of the War: RAMC o/s 14, vols $1,2$.
} 
Pasteur Institute, and Dr Frank Taylor of the Queen Alexandra Military Hospital, among others, for their assistance. ${ }^{107}$

J. A. Glover's account of the meningitis outbreak experienced at X Depot, 600 feet above sea level, on the chalk plateau of the South Coast, between October 1917 and May 1918, furnishes a good example this style of collegial acknowledgment, and is written with a vividness which lends drama to his account. 'Unprotected in any way from the east, or indeed form any other wind', Glover wrote, 'there is no bleaker spot in the south of England in the frosts and blizzards of such a winter as that of 1917'. In these conditions, recruits and returned Expeditionary men alike closed all the windows of their draughty huts as tight as possible, and 'enjoyed the very closeness of their overcrowded atmosphere'. ${ }^{108}$ Such conditions were now known to be highly favourable to the spread of meningitis from unidentified carriers, and on the first appearance of cases, the bacteriological team moved to action.

Glover's report on the outbreak and the measures taken to control it was generous in acknowledging the efforts and tribulations of his co-workers. Thus no differentiation in the types of meningococci involved in the outbreak was attempted, 'as Lt Col. Gordon's work was not then published'. ${ }^{109}$ Captain (Martin) Flack carried out 'a very thorough investigation' not only of the contacts of cases, but of the contacts of positive contacts. ${ }^{110}$ In January 1918, Flack became ill (illness unspecified), and his work was taken over by Captain W. Allen, until he too fell ill at the end of February (influenza of a mild type and bronchial cattarhs were recorded

\footnotetext{
107 M. H. Gordon and E. G. Murray, 'Identification of the meningococcus', no attribution, Wellcome Library, RAMC o/s 14, vol. 1, 411-23, 412, 416, 421. See publication details note 54 above.

108 J. A. Glover, 'The cerebro-spinal fever of 1917 at X Depot', Journal of Hygiene, 1918, 17, 350-65, 350.

109 Ibid, 352.

110 Ibid.
} 
as becoming prevalent at the time). ${ }^{111}$ By August, however, the meningitis carrierrate at X Depot had dropped to a level at which it seemed acceptable to try to prevent the return of the disease in the following winter. A scheme was produced with the help and co-operation of the Depot's Commandant, and of its Senior Medical Officer. This was submitted to Mervyn Gordon ('Lt. Col. Gordon of the Central Cerebro-Spinal Fever Laboratory') for 'valuable advice and criticism', before receiving the permission and backing of the authorities, particularly the 'very kind and prompt help of the D.D.M.S. and the S.S.O. of the District'. ${ }^{112}$ Among the subsequent precautionary measures taken was the creation of a special spray disinfection chamber with an external boiler and twenty Hine's jets, 'under the direction and supervision of Major Hine himself"' ${ }^{113}$

Major Macaulay Hine (1871-1937) was closely involved with the meningitis project from its inception. Before qualifying in medicine he had spent a year studying practical engineering in Germany. After time as a house physician at St Bartholomew's, he turned to bacteriology, investigating 'the fermentative character' of diphtheria bacilli -presumably under the guidance of Andrewes. When the meningitis problem raised its head in the winter of 1914/15, it was he who was appointed to run the mobile laboratory based at Millbank. ${ }^{114}$ By 1917 , he was well practised in dealing with meningitis outbreaks. 'As each salient point came to notice', his obituary-writer recorded, 'it was applied by Dr Hine'. Thus he identified a suitable medium to be supplied in bulk for identifying meningitis carriers, manufactured it on a large scale, and kept more than fifty laboratories dealing with troops supplied. When

\footnotetext{
111 Ibid, 354.

112 Ibid, 364.

113 Ibid, 365.

${ }^{114}$ Anon, 'Dr T. G. Macaulay Hine', Nature, 22 May 1937, 872.
} 
it was found that the only safe means of identifying meningococci was by serological methods, Hine undertook the large-scale production of agglutinating serums for identification of the strains involved and of homologous suspensions for checking the sera. When 'trial was made of monotypical therapeutic serum standardized by its antioxidant capacity', Hine undertook its distribution and assessment of the results. And when, finally, experiments on carriers at the Millbank laboratory showed that meningococci in the nasopharynx could be destroyed when men inhaled the air of a room 'densely charged with a spray of droplets of 1:50 zinc sulphate', Hine rose to the occasion by developing a more efficient jet spray than that currently in use, whose installation at X Depot, as noted above, he himself supervised. ${ }^{115}$

\section{Conclusion}

The example of $X$ Depot and the meningitis project as a whole show how the research undertaken with the aim of controlling epidemic meningitis among British troops during the war years was developed and finely calibrated by a team of researchers whose achievements were carefully recorded in the journal literature. In this literature, close team co-operation, and the consolidation of a research ethos, are visible in the systematic development of laboratory practices. Allbutt's transformation from observational craft to scientific calling is visible also in the life histories of the men and women whose war work and career experiences have been discussed here, and many of whose life trajectories were changed by the fortunes of war. Men who had intended to become general practitioners became world-class research scientists; a chemist became a renowned bacteriologist; a hospital pathologist became a distinguished epidemiologist; Harriette Chick, a bacteriological

\footnotetext{
115 Ibid. After the war, Hine served briefly in the new Ministry of Health before retiring to Somerset.
} 
research assistant, found a notable career in nutrition science. At the heart of these career changes lay experiences of disease occurrence mediated through laboratory procedures and discovery. The needs of war required a concentrated scientific focus on war-related problems of disease by scientists newly armed with particular skills in bacteriology, pathology, and biochemistry. Topley's laboratory-trained impatience with the old historical epidemiology was one manifestation of the intellectual rigour developed by the new laboratory science; the procedures adopted by the meningitis research team were another. In this process of scientific transformation, research into bacterial variation, nutrition science, epidemiology, and into a number specific conditions such as meningitis, bacillary dysentery, non-typhoid Salmonella, and gas gangrene, found a professional grounding for the first time in their history.

The impact on individual career patterns was not unique to the Great War: E. S. Anderson, Director of the Public Health Laboratory Service's Enteric Reference Laboratory (1954-78), perhaps best known for his views on the use of antibiotic growth promoters in animals destined for the human food chain, began his career as a GP, but after a military course in bacteriology during World War II, decided on a career in bacteriological research and public health. ${ }^{116}$ Taken in all, these histories suggest not only that the experiences of war changed the paths of individual medical lives, and contributed to knowledge in the immediate circumstances of conflict, but also that many such individuals went on in their post-war lives to enrich, and sometimes reshape, whole domains of medical knowledge.

${ }^{116}$ Anthony Tucker, 'E. S. Anderson', Education Guardian, 22 March 2006:

http://education.guardian.co.uk/obituary/story/0,1736616,00.html, accessed 20 December 2006. 